\title{
Is Our Water Safe To Drink?
}

\author{
Frederick Bloetscher*, Daniel E. Meeroff \\ Florida Atlantic University, United States \\ Email: fbloetsc@fau.edu
}

\begin{abstract}
Protection of the public health is the highest priority of any water system. For over 100 years, improvements to water treatment has decreased the number of deaths related to waterborne illness. For the most part in the United States and Canada, the risk of waterborne illness from a public water system is rare. However, when a failure occurs, the public mandates that come under scrutiny include the stewardship of the system (whether the responsibilities to protect public health, safety and welfare were met), the condition of the system (whether it has been maintained or allowed to incur deterioration and deferred maintenance) and operations practices (were the operations guidelines followed). Lawyers sue when they believe these mandates have not been met, that local officials have been poor stewards, or negligence exists. Failure to protect the public health, safety and welfare, creates a lot of legal liability for someone. Yet much can be learned from recent events concerning waterborne illness and public health risks, while identifying some guidelines to protect water systems from risk can be developed.
\end{abstract}

Keywords: waterborne illness, trihalomethanes

\section{Introduction}

Access to adequate, safe potable water supplies is a critical requirement for a stable society. That is why governments have attempted to manage this critical resource using public water works utilities. Ensuring that the utility system operates continuously is also of vital importance to ensure economic stability and public health in the community. Since Dr. John Snow's 1854 discovery in London that safeguarding drinking water supplies could protect people from communicable waterborne diseases, public utilities have understood that water treatment and distribution infrastructure can control the transmission of outbreaks of cholera and cryptosporidiosis, for example (Livernois, 2002).

After the industrial age began in earnest in the US, infrastructure investment grew exponentially. Solutions for poor sanitation conditions in urban streets began to be resolved by water conveyance systems that carried disinfected water to drink, sewer collection systems to remove waste, and the evolution of transportation from horses to automobiles, which reduced the manure lining the streets. With these early infrastructure systems came the ability to increase economic activity with limited adverse impact, leading to more investment in urban areas. Many of the northeast and midwestern infrastructure systems were built during this era of expansion. Many southern systems were initiated as a part of the Works Progress Administration (WPA) days of the Great Depression (1930s) because southern communities could not develop economically without water that was safe to drink and without proper waste disposal. However, the solutions, dumping the horse manure into the nearest river, dumping sludge in the ocean (as recently as the 1980s), discharging industrial waste directly to local rivers (the Cuyahoga River in Cleveland, OH burned regularly from 1866 through 1969 - over 100 years) brought about new challenges.

As a result, federal regulations were promulgated in the US starting with regulations on drinking water in 1914 and for domestic and industrial wastewater in 1948. These regulations and their subsequent reauthorizations (including both the Clean Water Act of 1972 and the Safe Drinking Water Act of 1974) were enacted to build new infrastructure to ultimately improve conditions. These important pieces of legislation included grant funding (subsequently converted to loan funds for state revolving fund programs) to help communities build the water and wastewater treatment plants, distribution networks and collection systems, many of which are in operation today.

The provision of safe drinking water and the collection, treatment and proper disposal of sewage in an environmentally safe manner is a public trust issue. In the United States, utilities will operate 24 hours per day, uninterrupted, to deliver adequate supplies of safe drinking water that are safe to drink 
(Bloetscher 2008, 2011, 2018, 2019) and protect the public from deleterious effects of exposure to raw sewage. While uninterrupted service is the goal, all systems experience failure, but for the most part, the failures are minor, last for a short time and have few if any long-lasting effects. In the cases where things go wrong and there are consequences, people remember because their expectations were not met. Meeting public expectations involves understanding the utility operating environment, performing planning activities and making timely financial decisions that will provide appropriate funding to achieve the utility's needs. For the most part, publicly owned water and sewer systems in the US comply with the applicable regulations on a consistent basis. Regulatory oversight is implemented to ensure consistency with respect to self-reporting on water quality and compliance issues. Failures in oversight can lead to failures in the field - i.e. when no one is reviewing the reporting, errors can go undetected. However, by their very nature (buried pipes and protected facilities that are out of the public view), water and sewer utility operations are not in the forefront in the minds of elected officials or local government management and finance personnel.

As a result, despite the public expectation that this infrastructure will operate continuously and protect the public health, the American Society of Civil Engineers gives a grade of D for drinking water and D+ for wastewater infrastructure (www.infrastructure reportcard.org) due to the lack of investment in the past 30 years. Further, the public rarely understands what is required to meet their expectations, a credit to the effectiveness to which these systems have been designed and operated for well over 100 years. Due the technical nature of water and sewer systems and the lack of understanding by local officials and the public, difficulties arise when trying to address the need to invest in upgrades, replacements or maintenance of these complex systems to ensure continuous uninterrupted and high quality service.

Ongoing infrastructure investment occurred during the post-World War II baby boom (Bloetscher, 2017, $2018,2019)$. The growth in local public water spending from 1972 to 2010 was $7.6 \%$ year-over-year (US Council of Mayors, 2015). However, during this period of growth, warnings about the lack of spending arose from the Federal Reserve Bank of Cleveland (Aschauer, 1989, 1990). In 1989, Duffy-Deno and Eberts (1989) estimated the shortfall between investment needed to provide "adequate" public infrastructure and available revenues to fund these projects would range from $\$ 17.4$ billion to $\$ 71.7$ billion annually by 2000 . For drinking water and wastewater systems, the "needs gap" was estimated at $\$ 500$ billion over 20 years. Anderson (2010), while the American Water Works Association (2012) estimated a $\$ 1$ trillion need for water systems Anderson (2010) with an additional $\$ 271$ billion needed for wastewater systems yet, spending decreased to $6 \%$ between 2001 and 2010 (US Council of Mayors, 2015). Maintenance and the desire to avoid spending exacerbates a potentially difficult problem.

Bloetscher $(2017,2018)$ showed that for utility infrastructure, the ratio of net plant assets (NPA) compared to the replacement value (RV) of the system should exceed $45.6 \%$. Assuming that $45.6 \%$ is the optimal percentage (Bloetscher 2017), less than half of US utilities surveyed in Florida, Ohio and Colorado met this goal, meaning that most are not in a position financially to meet future long-term protection of their service areas. The problem is particularly acute for smaller systems $(<10 \mathrm{MGD})$. Worse, another third was less than half this amount including a large percentage with a NPA/RV ratio less than $10 \%$, indicating that these systems have not been adequately maintained and suffer from a higher future potential for failure compared to better maintained systems. Compounding the problem, only $20 \%$ of the utilities had major capital projects, so the conclusion was that investments were made in large blocks as opposed to more pay-as-you-go methods (Bloetscher, 2018). This was partially confirmed by comparing the debt and the net plant asset/replacement value ratio - higher debt related to higher replacement values, meaning the investments were more recent.

According to the World Health Organization Global Health Observatory data (2016), diseases associated with unsafe water distribution, sanitation, and hygiene cause approximately 829,000 deaths annually, but these are not primarily US or Canadian utilities. The US Centers for Disease Control and Prevention (CDC) and the US Environmental Protection Agency (USEPA) have maintained a collaborative surveillance system for collecting and reporting waterborne disease outbreaks since 1971. For 1997 - 2006 , 137 waterborne disease outbreaks were reported to the CDC, with a total of 8,498 illnesses and 17 deaths (Barwick et al., 2000; Blackburn et al., 2004; Lee et al., 2002; Liang et al., 2006; Yoder et al., 2008). Of the outbreaks with a known cause (101), 17 were attributed to chemical or toxin poisoning and 84 to pathogens. Nonspecific bacteria were among the most commonly implicated pathogens. The highest number of outbreaks where the culprit was known were due to Legionella, Giardia, Campylobacter, 
norovirus and E. coli $\mathrm{O} 157: \mathrm{H} 7$ with $78 \%$ of outbreaks attributed to groundwater systems (Bloetscher and Plummer 2010).

Currently in the US, national primary drinking water standards regulate at least 88 contaminants in drinking waters, including several specific microorganisms (EPA816-F-09-004). These include the pathogenic microorganisms Cryptosporidium, Giardia lamblia, Legionella, E. coli, and enteric viruses, and several indicators of microbial risk and treatment system effectiveness, including heterotrophic plate count, total coliforms, and turbidity (Bloetscher and Plummer 2010). Some discussion of recent outbreaks is instructive in understanding the risk to public health.

\section{Milwaukee, 1993}

The City of Milwaukee, WI is a major metropolitan area. It has been served by the Milwaukee Water Works since 1874. On April 5, 1993, reports of gastrointestinal illness began to cause concern. Ultimately an estimated that 403,000 residents of the five-county area around Milwaukee had watery diarrhea attributed to the outbreak, which may have been an underestimation (McKenzie et al., 1994). The official outbreak-related attributable mortality was 69 deaths (Corso et al., 2003).

The organism was identified as a protozoan called Cryptosporidium parvum that was first identified as a human pathogen in 1976 (McKenzie et al. 1994). The source of the contamination was rainfall runoff from pasturelands that had recently applied manure as fertilizer. There were marked increases in the turbidity of treated water at the city's southern water treatment plant starting on March 23, 1993 (Hrudely and Hrudely, 2014). Testing of the waters after the outbreak indicated that while the rates of isolation of other enteric pathogens remained stable, but there was more than a 100-fold increase in the rate of isolation of Cryptosporidium spp. (McKenzie et al. 1994).

On April 5, 1993, the turbidity of treated water increased to $1.5 \mathrm{NTU}$, although turbidity was monitored only once every eight hours as opposed to continuously due to equipment failure. Throughout the period, samples of treated water from both plants were negative for coliforms and were within the limits set by the Wisconsin Department of Natural Resources for water quality (McKenzie et al. 1994). The economic losses were estimated in excess of $\$ 96$ million from illness and lost work time alone (Corso, et al 2003). Since 1993, Milwaukee Water Works has spent over $\$ 500$ million in infrastructure improvements and millions more has been spent on studying pathogens like C. parvum in water. USEPA passed the surface water treatment rules to try to avoid the situation in the future. Notably, for this incident there was no apparent negligence.

\section{Walkerton, Ontario, 2000}

Seven years after the Milwaukee incident, pathogens in Walkerton, Ontario sickened a large portion of the population. Walkerton is in a small, community near Lake Huron. The utility system was started in 1949 (WHQC, 2005), with surficial wells constructed for municipal water supply. In May 2000, the utility had three wells - Wells 5, 6 and 7, although only 5 was actually operational (WHQC, 2005). On May 18, 2000, twenty children were absent from Mother Teresa School, two of which were admitted to the Owen Sound hospital (O'Connor, 2002). Identification of the Walkerton outbreak was initiated at the hospital on May 19, 2000 (Bruce-Grey-Owen 2000). The next day, there were widespread reports of gastrointestinal illness with many more students unable to attend school (O'Connor, 2002a), and the region's Medical Health Office declared the outbreak, but later found out that local doctors had been treating patients with symptoms since May 17, 2000 (CBC News 2010). Testing of water samples from the distribution system on May 21, 2000 and of water from Well 5 on May 23, 2000 demonstrated significant contamination with coliforms and E. coli bacteria. Nearly half the population fell ill, and seven people died (CBC News, 2010).

The Provincial government assigned Justice Dennis R. O'Connor to lead the investigation into the events that precipitated this incident. Unlike the Milwaukee incident, Justice O'Connor found that the Walkerton incident was caused by errors and omissions by various individuals, as well as by systemic failures at the local, regional and provincial levels (Lindgren, 2003). Like Milwaukee, the contamination was ultimately due to manure application on a farm near Well 5 . While the owner of this farm followed proper practices, the well was located at the lower end of the field, and the well seal was not properly 
maintained so runoff contaminated the well. Justice O'Connor noted that the Ministry of the Environment had failed to inspect and require the well seal to be corrected (O'Connor, 2002a). In addition, the Walkerton Public Utilities Commission operators lacked the training and expertise necessary to identify either the vulnerability of Well 5 to surface contamination or the resulting need for continuous chlorine residual and turbidity monitoring (O'Connor, 2002a). O'Connor (2002a) noted that the operators had engaged in a host of improper operating practices, including failing to use adequate doses of chlorine, failing to monitor chlorine residuals daily, making false entries about residuals in daily operating records, and mis-stating the locations at which microbiological samples were taken for many years, and that the operators knew that these practices were unacceptable and contrary to regulatory guidelines and directives. Further, no action was taken by the utility managers of the City of Walkerton, and the concerns were not transmitted to higher authorities. The public utility committee's (PUC) general manager concealed information about a chlorinator being off-line and water quality test failures from water samples taken on May 15 from the local Health Unit (O'Connor, 2002a). Had he disclosed either of these facts, the health unit would have issued a boil water advisory on May 19, and many illnesses would have been avoided (O'Connor, 2002a).

Within the utility, the Public Utility Commission (PUC) commissioners were not made aware of the improper treatment and monitoring practices of the operators. However, those who were commissioners had failed to properly respond to a Ministry of the Environment inspection report in 1998 that set out significant concerns about water quality and identified several operating deficiencies at the PUC. In addition, the provincial Ministry of the Environment should have, but did not detect the problem, nor was any effort undertaken to address the practices of the operators. Justice O'Connor indicated that the provincial government's budget reductions that led to the discontinuation of government laboratory testing services for municipalities in 1996 was partially to blame (O'Connor, 2002a). Such independent testing might have uncovered the prior test failure and operational deficiencies (chlorine residuals), causing enforcement action and boil water notifications in time to avoid the outbreak. Justice O'Connor recommended a new regulation mandating that testing laboratories immediately and directly notify both the Ministry of the Environment and the Medical Officer of Health of any noncompliant results. Had the government done this, the boil water advisory would likely have been issued by May 19, 2000, thereby preventing an important number of infections and possibly all of the deaths (O'Connor, 2002a). He also suggested that boil water advisories should be more broadly disseminated because some residents of Walkerton did not become aware of the boil water advisory that was issued on May 21, 2000.

Justice O'Connor found that inadequate funds had been allocated by the community government for public utility oversight which limited the ability of the town and its manager to oversee the utility (WHQC, 2005). The failure of the local government to allocate funds, or to involve themselves in the affairs of the utility they oversaw, also was a causal concern. There was a demonstrated need by the utility and regulatory agencies to ensure that multiple barriers of protection for public health protection were needed. These were not provided. Environmental factors were not considered - a well at the downstream end of a farm field on which manure was applied would appear to be an obvious potential health issue, but it was not addressed by the utility, local government or regulatory agencies (WQHC, 2005). Ultimately, the economic cost of the Walkerton tragedy was estimated to be more than $\$ 64.5$ million (Livernois, 2002). Financial resources, regulatory and management oversight and stewardship all failed the public in this instance. If responsibility had been taken by anyone at any point, the incident likely would not have happened.

\section{Alamosa, CO - 2008}

Alamosa, CO is a city of 8,900 people in southern Colorado. Alamosa's water system distributes over 800,000 gallons of water per day through 50 miles of distribution pipe (Falco and Williams, 2009). The City relies on deep artesian wells for its water supply. The well permits were issued between 1963 and 1983. Records also appear to indicate that original well construction was as early as 1936 for the Cole Park well and 1956 for the Weber well (Falco et at., 2009). Falco and Williams (2009) note that the aquifer is considered to be a protected groundwater source by the state and as a result, a waiver from the statewide requirement for disinfection was granted to Alamosa in 1974. This means that the city's drinking water was not chlorinated for disinfection. Not chlorinating the water saves money for the City by reducing 
chemical costs and monitoring requirements. The city was deemed to be in compliance with all healthbased drinking water standards, with the exception of the arsenic standard, which required a treatment plant be built years earlier.

During the second week of March 2008, multiple residents of Alamosa fell ill with severe gastrointestinal symptoms, (Marler, 2015). On March 17, 2008, the Colorado Department of Public Health and Environment (CDPHE) notified the Centers for Disease Control and Prevention (CDC) that 18 Alamosa residents who had fallen ill in the month of March 2008 had tested positive for Salmonella typhimurium, and that 19 others were suspected to be suffering gastrointestinal symptoms from the same organism. Random water sampling from the City's water system confirmed that the distribution network was heavily contaminated by Salmonella typhimurium and was thus the source of illness in the developing outbreak (Marler, 2015). Colorado's chief medical officer and CDPHE issued an order on March 19, 2008 requiring the City of Alamosa to advise its residents to drink only bottled water (Marler, 2015). As of that date, at least 79 people were believed to have been infected by the heavily contaminated public water supply. Ultimately, the outbreak resulted in 442 reported illnesses, 122 of which were laboratory-confirmed, and one death (Falco and Williams, 2009). Epidemiological estimates suggest that up to 1,300 people may have been ill (Falco and Williams, 2009).

Based on a review of records and interviews with utility workers, the city did not maintain a program of routine flushing, disinfecting, or removing sediment from their tanks as part of routine operations. In fact, according to Falco and Williams (2009), at the time of the outbreak, the city did not have an active distribution system maintenance and flushing program or a cross-connection control program. All the distribution crews did was respond to line breaks.

It was later noted that the Weber reservoir was in poor condition and poorly maintained for a number of years. It was suggested that the contamination may have entered this reservoir though snowmelt, small animals or fecal contamination. The treated, high quality, ground water was stored in a reservoir that was not sealed, thereby negating the protection provided by the aquifer.

On October 10, 2008, CDPHE signed an Enforcement Order on Consent ("consent agreement") for violations related to the Salmonella outbreak. The requirements included: continuous chlorination of the well sources, ongoing monitoring of water quality in the distribution system, cooperation with CDPHE on the investigation into the cause of the outbreak, and submittal of other technical and administrative documentation (Falco and Williams, 2009). A lawsuit was filed against the City claiming that the city was negligent in maintaining its water facilities and had sold tainted water to its customers was settled on September 16, 2010, whereby the City of Alamosa, through its insurance carrier, would pay $\$ 360,000$ to 29 Alamosa residents who became ill because of the outbreak in 2008 (Marler, 2015).

\section{Flint, Michigan 2014-17}

Six years after Alamosa, was Flint, although much of the public outcry did not arise until later in 2014 and 2015. Flint's first water plant was constructed in 1917. The source of water was the Flint River. This plant was abandoned in 1952 when the City's second plant was constructed (note the original plant is still located in dilapidated condition on the east side of the current plant). Because of declining water quality in the Flint River, the city had made plans to build a pipeline from Lake Huron to Flint in 1962, but a real estate scandal caused the city commission to abandon the pipeline project in 1964 and instead buy water from the City of Detroit (who's source is Lake Huron). Flint stopped treating its water in 1967, when a pipeline from Detroit was completed (Flint Water Advisory Task Force 2016). Starting in 1967, the City of Flint purchased almost 100 MGD from Detroit. While the City of Flint had purchased water for years from Detroit, the 60-year-old Flint water treatment plant had been maintained as a backup to the Detroit system, operating approximately 20 days over that 60 years at 11 MGD.

In 2010, Detroit declared bankruptcy, and Flint declared bankruptcy about the same time. By that time the amount of water being purchased by Flint had decreased to under 14 MGD (Flint Water Advisory Task Force 2016) as industry left and the population diminished. Between 2011 and 2015, Flint's finances were controlled by a series of receivers/emergency managers appointed by the Governor as were Detroits (different receivers however). Both receivers were told by the Governor to reduce costs (the finance/business decisions - Flint Water Advisory Task Force 2016). Public health was not a priority. 
In 2010, the City of Flint joined the Karegnondi Water Authority (KWA) which consisted of a group of local communities that decided to support and fund construction of a raw water pipeline from Lake Huron for raw water. Flint was one of the communities, and the concept was for Lake Huron water to be delivered to the 1952 Flint water plant for treatment. Since Flint was in bankruptcy at the time, final approval of the deal was delayed until the state and emergency manager approved of the agreement (Flint Water Advisory Task Force 2016). While discussions were ongoing for several years thereafter, the Detroit Free Press reported a 7-1 vote in favor of the KWA project by Flint's elected officials in March 25, 2013 (City of Flint, 2016). An engineer's report noted that a Genesee County Drain Commissioner stated that one of the main reasons for pursuing the KWA supply was the reliability of the Detroit supply given the 2003 power blackout that left Flint without water for several days (City of Detroit, 2013). Another issue was that Flint had no say in the rate increases issued by Detroit.

As expected, the City of Detroit objected due to loss of revenues at a time when a receiver was trying to stabilize the city's finances (in conjunction with the State Treasurer, City of Detroit, 2013). In 2013, the City of Detroit made a final offer to convince Flint to stay on Detroit water with certain concessions. Flint declined the final Detroit offer and Detroit gave Flint notice that their long-standing water agreement would terminate in twelve months, meaning that Flint's water agreement with Detroit would end in April 17, 2014. However, construction of KWA was not expected to be completed until the end of 2016 (TYJT, 2013; City of Flint, 2016).

On June 23, 2013, an engineering firm was hired to design and oversee a $\$ 7$ million renovation/upgrade to the old Flint River plant to allow the filters to treat Flint River water (Flint Water Advisory Task Force 2016). The project was designed to take water from the Flint River for a period of time until a Lake Huron water pipeline was completed (Fonger, 2015). Flows were designed for 16 MGD. Lime softening, sand filters and disinfection were in place but water quality testing was suggested to have been lacking. The operations staff noted that there was pressure to start the water supply from the Flint River from local officials on April 16, 2014 (Flint Water Advisory Task Force 2016). The City of Flint began using the Flint River as a water source on April 29, 2014 knowing that treatment would need to be closely watched since the Michigan Department of Environmental Quality, in partnership with the U.S. Geological Survey and the City of Flint Utilities Department, had conducted a source water assessment and determined the source had a very high susceptibility to potential contaminant sources (Cooper, 2004).

The change in water quality and treatment created water quality challenges that resulted in water quality violations. Like most older, northern cities, the water distribution system was almost 100 years old. Many of the service lines from the cast iron water mains (with lead joints) to customer's homes were constructed with lead goosenecks and copper and lead service lines. Lead piping exists within many houses.

The potential impact of lead in children engendered the lead and copper rule of the late 1980s. In the early 1990s, water systems addressed this rule by testing and by corrosion control additives. The concept was that on the first draw of water in the morning, the lead concentration should not exceed $0.015 \mathrm{mg} / \mathrm{L}$ and copper should not exceed $1.3 \mathrm{mg} / \mathrm{L}$. Depending on the size of the utility, sampling was to be undertaken twice from a random set of houses, with the number of samples dependent on the size of the system. The sampling was required to be performed twice, six months apart (note routine sampling has occurred since then to ensure compliance). Residents were instructed on how to take the samples, and results were submitted to the appropriate regulatory agencies. If the system came up "hot" for either compound, the utility was required to make adjustments to the treatment process. Ideally water leaving the plant would have a slightly negative Langlier saturation index (LSI) and would tend to slightly deposit on pipes. Coupon tests could be conducted to demonstrate this actually occurred - as they age, the pipes develop a scale that helps prevent leaching. Most utilities tested various products in 1989/1990. Detroit clearly did this and there were no problems.

While this testing was done in 1989/1990, Flint did not do this testing in 2013/2014 (Flint Water Advisory Task Force, 2016). The water quality in Flint River water is different than the water quality coming from Detroit with respect to salinity, TOC, $\mathrm{pH}$ and overall aggressiveness of the water (as measured by how easily it might dissolve the pipe) was significantly greater. The variable flow rates in the river, with upstream agriculture, industry and a high potential for contamination, make it nowhere near as easy to treat as the water from Lake Huron. Accommodations were not made to address the problem, and the state found no polyphosphates were added to protect the pipes against corrosion. Veolia reported that the operations needed changes, including new treatment processes (granular activated carbon filtration), and operators needed training (Fonger, 2015). 
As a result, Flint appears to have sent corrosive water into the piping system, which dissolved the scale that had developed over the years from the Detroit water, exposing raw metal, and created a lead, copper and iron leaching issue. Virginia Tech researchers reported found that at least a quarter of Flint households have levels of lead above the federal level of $15 \mathrm{ppb}$, and as high as 13,200 ppb (Lazarus, 2017). Tests showed Flint River water without added phosphates corroded the lead at 19 times the rate of Detroit water (Ganim and Tran, 2016). Once the switch was made, the state began testing for lead and copper at the tap in customer's homes, as is required by the USEPA. The first round of testing completed in December 2014 showed lead levels of up to $6 \mu \mathrm{g} / \mathrm{L}$ at the tap, likely from lead service lines and copper lines with leaded solder. The second round, completed in June 2015, found up to $11 \mathrm{\mu g} / \mathrm{L}$ of lead in the service lines (Wisely and Erb, 2016). The USEPA requires a remediation plan when lead levels reach 15 $\mathrm{\mu g} / \mathrm{L}$. Aging cast-iron pipe compounded the situation, leading to aesthetic issues including taste, odor and discoloration that result from aggressive water. Once the City started receiving violations, public interest and scrutiny of the drinking water system intensified.

In May and August of 2014, total trihalomethane (TTHM) samples violated the drinking water standards (Flint Water Advisory Task Force 2016). This means two things - total organic carbon (TOC) precursors were present in the water, and excessive chlorine was being added to disinfect and probably reduce color caused by the TOC. Of interest, Flint's plant is a lime softening plant. Lime softening does not remove TOC and is not generally used for surface water treatment, and filtration is not very effective in removing TOC either (Zazouli or Kalankesh, 2017). Elevated TOC usually requires granular activated carbon adsorption, ion exchange or membrane treatment for removal, but the Flint plant used none of these.

To address the TTHM issue, chlorine dosage appears to have been reduced as the TTHM's were in compliance by the next sampling event in November 2014. However, in the interim, new violations included a total coliform and E. coli in August and September of 2014 (Flint Water Advisory Task Force 2016), an indirect indication of reduction in chlorine dose. Due to inadequate disinfection, residents had to boil their water. Just when things were to improve in the media, a hospital in Flint reported in January 2016 , that low levels of Legionnella bacteria were discovered in the water system and that 10 people had died and up to 85 were affected back in 2014. Shigella was also reported (McFarland and Anderson 2016). The source is unclear, but when chlorine residuals are low, microorganism growth will occur (Bloetscher et al. 2010).

In October 2015, the water supply was switched back to Detroit, and the City started adding additional zinc orthophosphate in December 2015 to facilitate the buildup of the protective scale eroded from the pipes by the Flint River water. It will take some time for the scale to build back up to previous levels and to lower lead concentrations, leaving the residents of Flint at risk because of a business/finance/political decision that had not considered public health impacts. It also indicates that the chemistry profile and sampling prior to conversion and startup was not fully performed to identify the potential for the lead leaching to occur.

Residents, the former mayor, the current mayor, Congressman Kildee, city workers - all blame the Governor's office and the Michigan Department of Environmental Quality (Ganim and Tran, 2016). The state's focus on balancing the city's books and choosing to reduce costs over public health consequences appears to have created an eventually more expensive public problem (Shepardson, 2016). If the due diligence of engineers was not undertaken as to water quality impacts of the change in source water, the engineering design effort appears to have been flawed. If the engineer recommended this work, but was denied by the receivers, it creates another flawed business decision that fails the public health test. Clearly there were also issues with operations. Telling the state phosphates were used when they were not, appears to be operations malfeasance. Veolia came to a similar conclusion (Fonger, 2015). The state has received its share of blame in the press. The regulatory staff was reduced as the state trimmed its budget, but it is unclear if there were sufficient resources to insure oversight of water quality. The lack of provincial resources to monitor water quality was an issue in Walkerton - lack of oversight compounded local issues. Multiple state and local employees were indicted.

\section{Florida Utility Woes}

Five years later, a Florida water plant ran into issues with water quality in its distribution system. The 
utility owns, and has operated under contract since 2012, a lime softening water treatment plant. The plant runs at $2 / 3$ capacity on the average day and has a history of being compliant with all regulations. However, since contracting operations, while there are no reported illnesses, it appears that water quality in the distribution system has deteriorated. Recent sampling indicated a trihalomethane violation, a lack of chlorine residuals, higher color in the water, nitrification in the distribution system and a potential Legionella issue. Plant issues that have been reported are:

- The ion exchange resin is poisoned with calcium carbonate

- The filter media is covered with lime sludge and needs to be changed

- Sludge does not settle quickly

- Backwash rates are higher, and

- The blowdown from the accelators is higher

Lime softening processes are relatively efficient at removing both the bacteria and the hardness in raw groundwater if the proper dosages are used (Hammer and Hammer, 2013). When the correct $\mathrm{pH}$ is achieved $(>10.3)$, large calcium carbonate particles settle quickly, thereby removing calcium and magnesium hardness, along with iron, and other polyvalent cations in a clarification zone and creating lime sludge. The softened water then flows out through weirs on the top of the reactor/clarifier units to filters for removal of any remaining suspended materials.

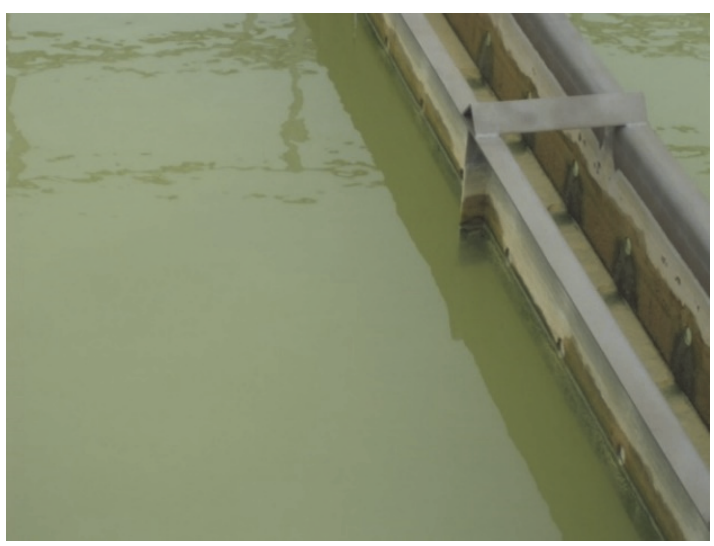

Figure 1. Poor settling $(\mathrm{pH}<9.5)$

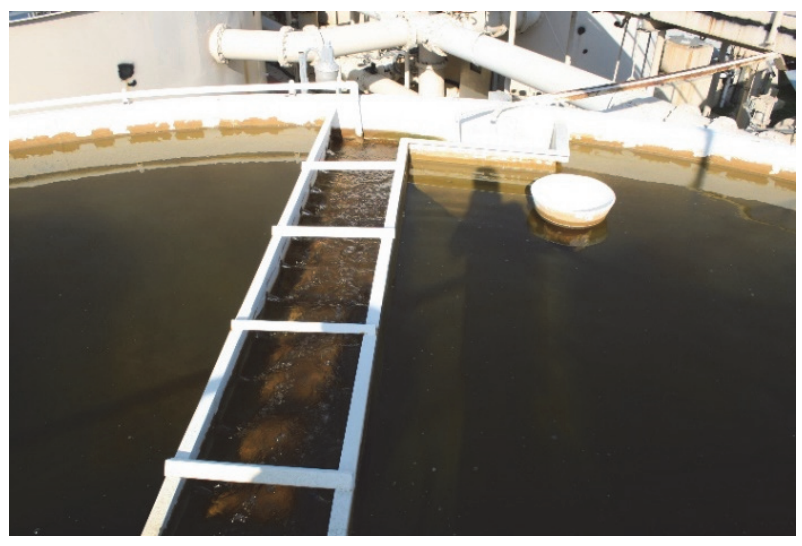

Figure 2. Settling $(\mathrm{pH}>10)$

Based on the raw water quality for this Florida utility, the required lime dose should have been about $1400 \mathrm{lbs} / \mathrm{MG}$. Spot reviews of records in 2008, 2011 and 2013 when City staff operated the plant indicated about 1200-1300 lbs/MG was used. More recently, the contract operator has reported $700 \mathrm{lbs} / \mathrm{MG}$ of lime to save over $\$ 1$ million per year in chemical costs for the vendor. The operating $\mathrm{pH}$ is much lower as a result. When insufficient lime is used, settling will be hindered (compare Figures 1 and 2) and the $\mathrm{pH}$ is less than 9.5. Poor settling of the lime sludge creates two issues - higher volumes of sludge (less solids, more liquid) and carryforward where the sand and anthracite in the filters act as a catalyst for the calcium bicarbonate, and through to the ion exchange resins that attract the calcium bicarbonate. The researchers observed the following:

- Because the $\mathrm{pH}$ is not high enough, solids do not settle readily, creating cloudy water in the clarifier portion of the accelators

- The amount of lime sludge waste is higher than when the lime softening system was operating properly

- Cloudy filters due to carryover from the accelators (see Figure 3; Figure 4 is a comparison to a properly operated filter)

- Backwash times are over twice what they should be for a lime softening system

- Increased particle size of sand and anthracite filtration media (compare Figures 5 and 6 to the actual media in Figure 7), which means the anthracite, which effectively acts as granular active carbon for organics removal, cannot practically remove organics (Selbes, 2017), and the swelled grains are less effective at filtering other contaminants, so carryover occurs

- Poisoned ion exchange resins as the carryover from the filters plated onto the ion exchange media 
(see Figure 8, versus what the media should be in Figure 9). The City's engineers identified organics and color as issues and installed an anion exchange system to address the potential for color and trihalomethane issues

- Increased disinfectant demand due to the added fine suspended material decreasing the effectiveness of disinfection, and requiring a higher disinfection dose, leading higher TTHMs

- A pH of less than 8.6 may stimulate the occurrence of nitrifying bacteria in the distribution system (the operations goal was a $\mathrm{pH}$ of 8.4)

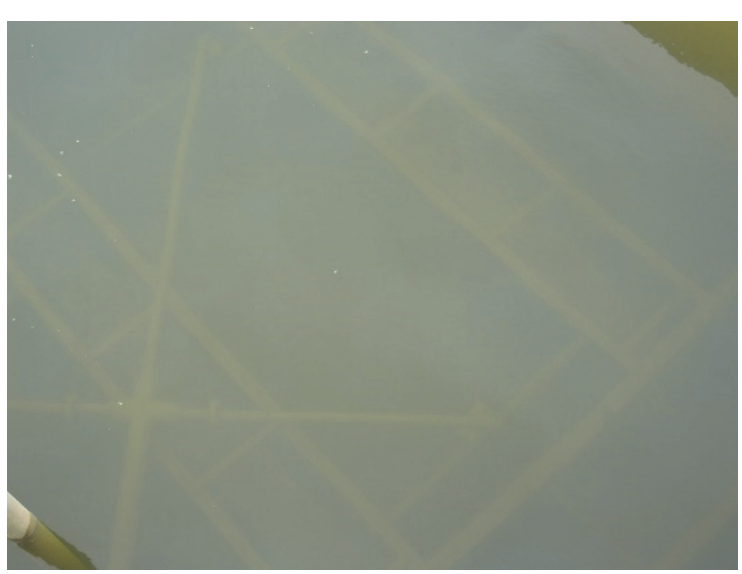

Figure 3. Cloudy filter

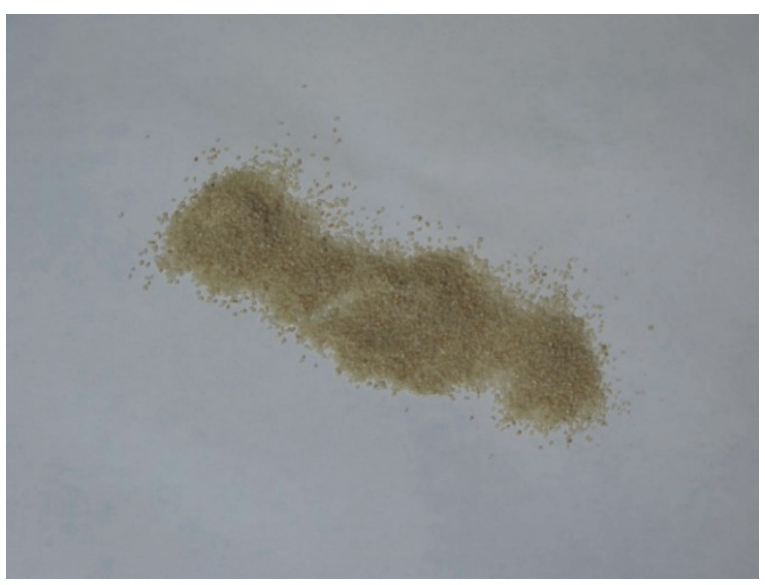

Figure 5. The actual sand media

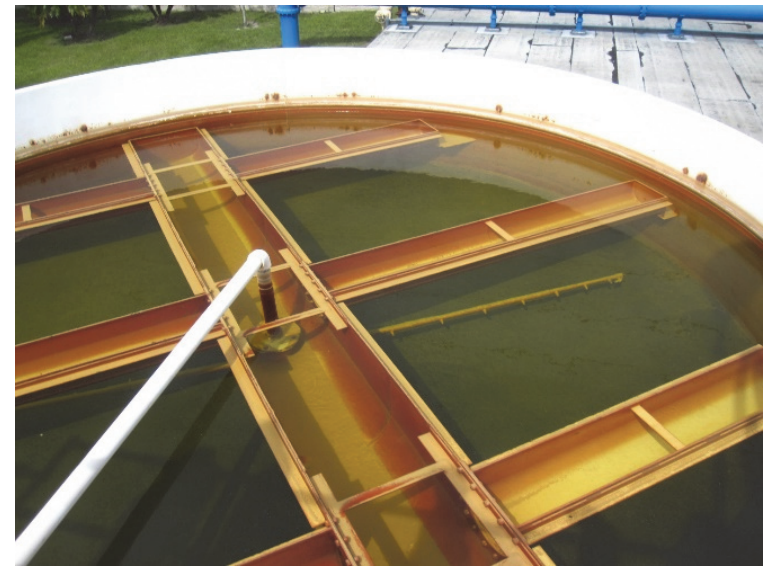

Figure 4. Typical filter operating normally

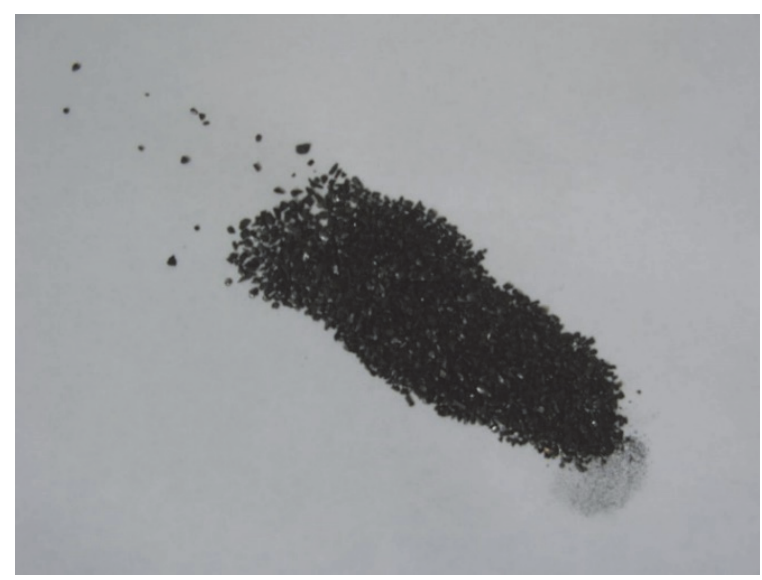

Figure 6. Anthracite media

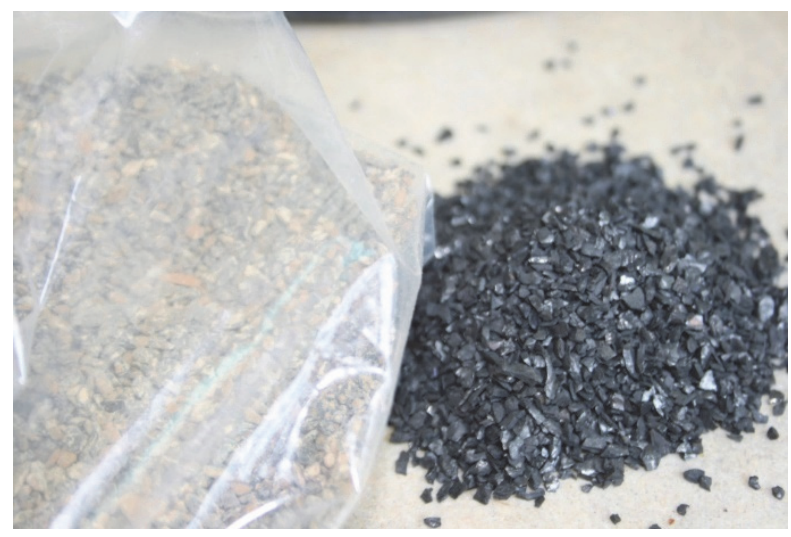


Figure 7. Comparison of anthracite and actual media

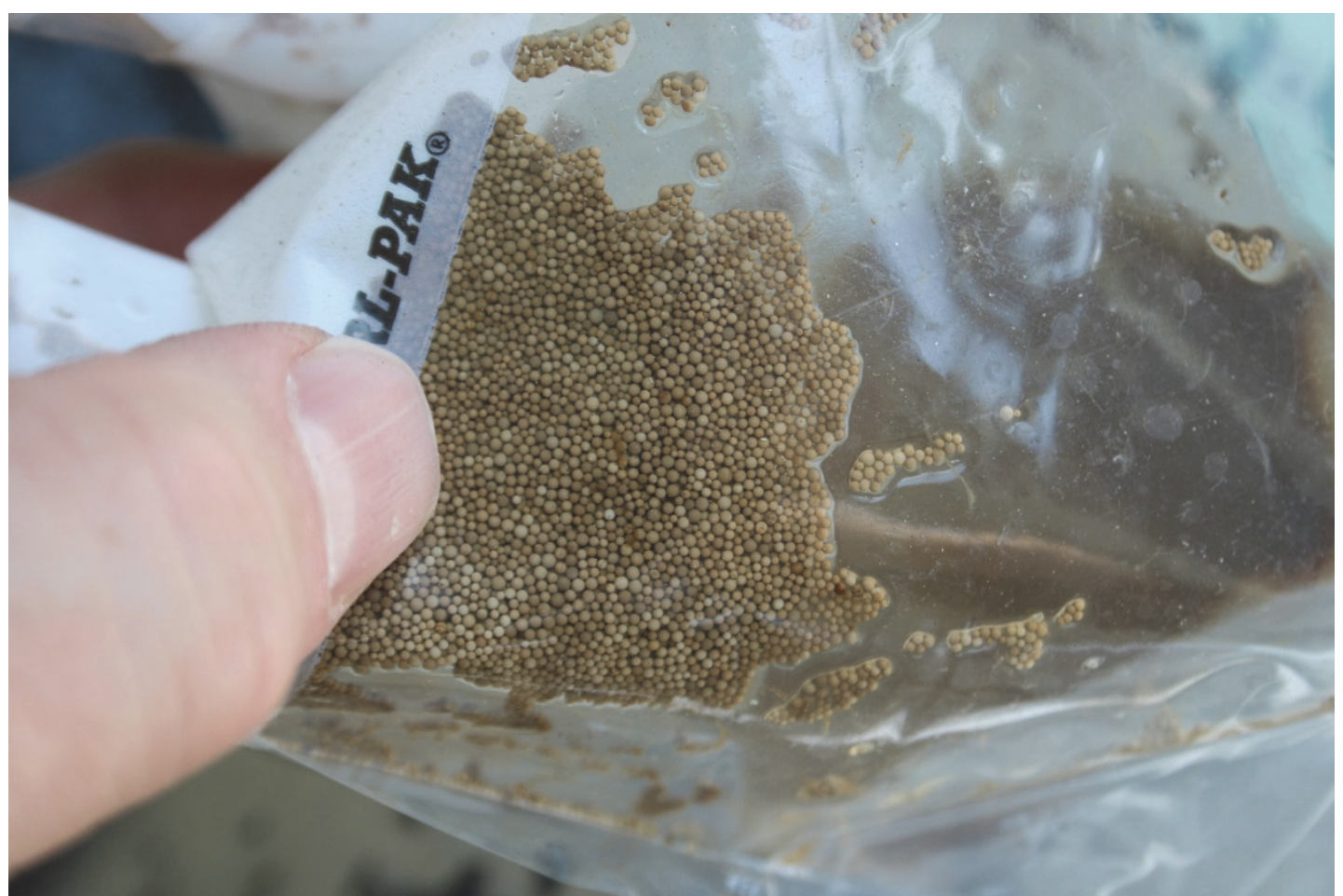

Figure 8. Poisoned Ion exchange media

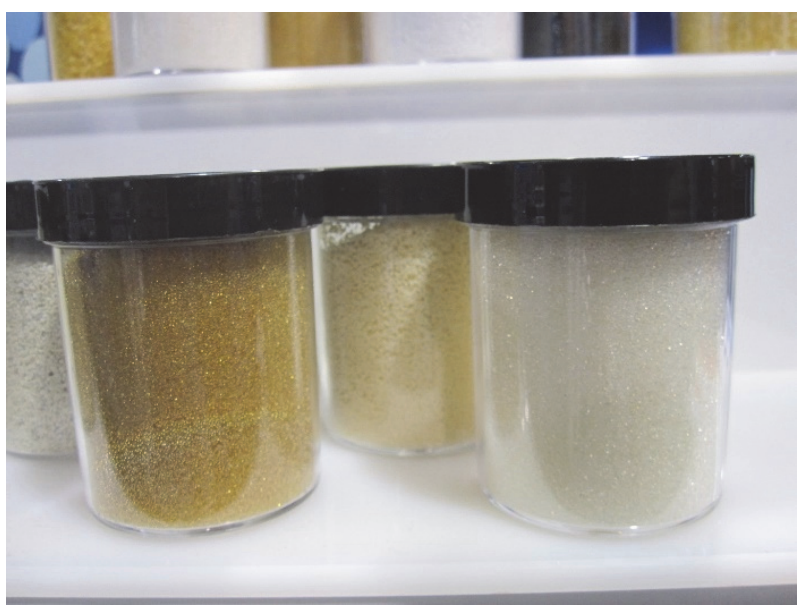

Figure 9. What ion exchange media should look like

\section{$7 \quad$ Major Findings}

In reviewing these five case studies, several observations can be made. Milwaukee, WI was a surface water source. Turbidity from runoff led to pathogen contamination, even though sampling showed no coliform violations. The issue was that the absence of coliform indicators does not signal the absence of all pathogens. There are many constituents that are not routinely tested for, and not all pathogens can be detected. Despite proper operations, a problem occurred. Walkerton, ON was a groundwater source. However, the system was not maintained properly, and a cascading series of failures involving training, sampling, and follow-up procedures led to a public health crisis. Equipment must be properly maintained, 
and routine checks on system operations are critical. In Alamosa, CO, disinfection was shown to be needed to protect the piping system. Many believe disinfection only applies to the finished water leaving the plant, but the piping system also requires a residual to maintain control of microbial growth in the distribution network. The lack of upkeep to the piping and storage, as opposed to the raw water supplies, created the public health crisis. Cost savings were part of the issue as was follow-up to the operations. In Flint, MI, rising costs and politics led to a cascade of poor decisions that ultimately brought about a public health crisis. There was no follow-up on operations, little investment in maintenance or capital projects, and a general lack of following procedures that created the issues. Stability of the water was a major concern leading to the lead issue as were TTHMs and pathogens in the water distribution system. In the Florida example, the utility was seeking cost savings by contracting operations, which led to a lack of oversight of the operations vendor and how they altered treatment, which then led to a multitude of problems, including plant equipment failures, water quality issues, TTHMs, biofilms and nitrification in the distribution system.

\section{Conclusions}

When a failure occurs at a water treatment facility, the public mandates that come under scrutiny include the stewardship of the system (whether the responsibilities to protect public health, safety and welfare were met), the condition of the system (has it been maintained or allowed to incur deterioration and deferred maintenance) and operations practices (were the operations guidelines followed). All of the case studies outlined here over a 25-year period included water quality issues that impacted the public health of their customers. In all cases, biological contaminants were present. Over that same period, there were 670 waterborne illness outbreaks in water distribution systems the US. Given that there are over 54,000 water systems, and only $1.2 \%$ of the systems had documented failures over that period, the annual incidence was $0.05 \%$ or 1 in 735,000 on any given day - nearly equivalent to the 1 in 1 million goal set for regulatory standards. Most of the utilities that experienced failures were very small systems. Only 4 made national headlines because they were large, public systems. However, there is more that can still be done to make the incidence of failure less.

The findings of Bloetscher $(2017,2018)$, and the investigators for each of these system failures noted herein revealed that funding was a major cause. Across the US and Canada, utilities are underfunded, and under-invested. To reduce potential health risks, this needs to change despite the desire by rate-payers to keep their rates low. In part, this is why utility staffs, who are keenly aware of the potential risks to providing service to the public, often include redundancy in the physical infrastructure and use the best quality materials they can acquire. They will maintain an inventory of parts and sensors to maintain equipment and be prepared for the inevitable failures that will occur. Training of staff, and understanding the needs for regulatory compliance are critical to long-term efforts. Elected and appointed officials need to recognize that it is the lack of spectacular failures with infrastructure systems that should be recognized and appreciated by the public, not the infrequent failures that no system can avoid. In addition, regulatory oversight was lacking in several of the case studies. As states and counties attempt to reduce costs, oversight agency budgets are often cut. Alamosa, Flint and Walkerton all have budget issues with the states. Assuming that self-monitoring will ensure public health, is contradicted repeatedly throughout history. The water industry is no different.

Only certain contaminants are monitored. As a result of the Milwaukee incident, USEPA developed a program to identify candidate contaminant lists (CCL) under the Unregulated Contaminant Monitoring Rule (UCMR). The 1996 amendments to the Safe Drinking Water Act limited USEPA to regulating no more than 30 new constituents each 5-year period. To develop the list, USEPA requires utilities to samples for thousands of compounds nationwide to determine which are occurring more regularly, and then assess their likely impact on public health. As of 2016, USEPA is on UCMR4. However, that does not guarantee that the next large scale outbreak will not be missed.

\section{References}

1. 64E Division of Environmental Health And Statewide Programs Chapter 64e-1 Certification Of Environmental Testing Laboratories, Florida Statutes, accessed 6/1/2017. 
2. Anderson, R.F., 2010. Trends in Local Government Expenditures on Public Water and Wastewater Service and Infrastructure: Past, Present, and Future. The US Conference of Mayors-Mayors Water Council, Washington

3. Ammann, P., Laethem, C. L., and Kedderis, G. L. 1998. Chloroform-induced cytolethality in freshly isolated male B6C3F1 mouse and F-344 rat hepatocytes. Toxicol. Appl. Pharmacol. 149, 217-225.

4. APHA. 2017. Standard Methods for the Examination of Water and Wastewater, $23^{\text {rd }}$ Edition, American Water Works Association/American Public Works Association/Water Environment Federation, Washington, DC.

5. Barrett, S.E., M.K. Davis, and M.J. McGuire. 1985. Blending Chloraminated and Chlorinated Waters. Jour. $A W W A(1): 50-61$.

6. Bloetscher, F. 2011. Utility Management for Water and Wastewater Operators, AWWA, Denver CO.

7. Bloetscher, Frederick; Polsky, C.; Bolter, K.; Mitsova, D.; Pablicke Garces, K.; King, R.; Cosio Carballo, I.; and Hamilton, K. 2016. Assessing Potential Impacts of Sea Level Rise on Public Health and Vulnerable Populations in Southeast Florida and Providing a Framework to Improve Outcomes, Sustainability 2016, 8(4), 315; doi:10.3390/su8040315.

8. Bloetscher, F. 2008. Water Basics for Decision Makers: What Local Officials Need to Know about Water and Wastewater Systems, America Water Works Association, Denver, CO.

9. Brinkley, D. 2015. The Broken Promise of the Levees That Failed New Orleans, Smithsonian Magazine September 2015, http://www.smithsonianmag.com/smithsonian-institution/broken-promise-levees-failed-new-orleans180956326/\#dgtHH72yWi5Tcler. Accessed 12/13/16.

10. Bruce-Grey-Owen 2000. The Investigative Report Of The Walkerton Outbreak Of Waterborne Gastroenteritis May - June, 2000 Bruce-Grey-Owen Sound Health Unit, Toronto, ON?

11. CBC News 2010. Inside Walkerton: Canada's worstever E. coli contamination CBC News Posted, May 10, 2010, CBC/Radio-Canada.

12. City of Detroit, 2013. Water War Undermines Flint-DWSD Relations 4/1/2013

13. City of Flint, 2016. State of Emergency Declared in the City of Flint, City of Flint, MI. https://www.cityofflint.com/state-of-emergency/ accessed 3/15/16.

14. Cooper, J. 2004. A Biological Assessment of the Flint River and Selected Tributaries in Lapeer, Genesee, Oakland and Saginaw Counties, Michigan. June 30- August 2003. Surface Water Quality Assessment Section, Water Bureau, Michigan Department of Environmental Quality, MI/DEQ/WD-03/114.

15. Corso, P.S.; Kramer, M.H.; Blair, K.A.; Addiss, D.G.; Davis, J.P. and Haddix, A.C. 2003. Cost fo Illness in the 1993 Waterborne Cryptosporidium Outbreak, Milwaukee, Wisconsin, Emerging Infections Diseases, V9:4. pp. 426433. https://dx.doi.org/10.3201/eid0904.020417.

16. Falco, R. and Williams, S.I. 2009 Waterborne Salmonella Outbreak In Alamosa, Colorado March And April 2008 Outbreak Identification, Response, And Investigation, Colorado Department of Public Health and Environment, Denver, CO.

17. Federal Register. December 16, 1998. National Primary Drinking Water Regulations. Disinfectants and Disinfection Byproducts. Final Rule. Federal Register. (63 FR 69390).

18. Flint Water Advisory Task Force. 2016. Final Report. http://www.michigan.gov/documents/snyder/ FWATF_FINAL_REPORT_21March2016_517805_7.pdf (accessed October, 22, 2016).

19. Fonger, R. 2015. Flint water consulting team gets $\$ 900$ an hour for advice; Report due next week 2/28/15.

20. Fonger, R. 2015a, Flint water consultant's final report recommends $\$ 3$ million in changes, 3/18/15.

21. Ganim, S. and Tran, L. 2016. How tap water became toxic in Flint, Michigan, updated 10:53 AM ET, January 13, 2016, https://www.michigan.gov/documents/snyder/fwatf_final_report_21march2016_517805_7.pdf

22. Grady, C.P.L, Jr., and H.C. Lim, 1980. Biological Wastewater Treatment. Marcel Dekker, NY

23. Holt, David, Rory D. Todd, Anaick Delanoue, and Jennifer S. Colbourne. 1995. A Study of Nitrite Formation and Control in Chloraminated Distribution Systems. In Proc. 1995 AWWA Water Quality Technology Conference; Part II. Denver, Colo.: AWWA.

24. Kim, P.H-S, and Symons, J.M., 1991, Using Anion Exchange REsins to Remove THM Precursors, JAWWA, 83

25. Lazarus, O, 2017, In Flint, Michigan, a crisis over lead levels in tap water, Public Radio International, Minneapolis, MN. https://www.pri.org/stories/2016-01-07/flint-michigan-crisis-over-lead-levels-tap-water. Accessed 1/20/17

26. Lindgren, R. D. 2003. In The Wake Of The Walkerton Tragedy: The Top 10 Questions, National Symposium on Water Law (Canadian Bar Association, Vancouver, March 28 \& 29th, 2003, Canadian Environmental Law Association, Toronto, Ontario. Publication No. 440 ISBN No. 1-894158-83-0.

27. Marler, W. 2015. Salmonella Litigation A resource for Salmonella Outbreak Legal Cases link: Alamosa, Colorado, Municipal Water System Salmonella Outbreak Litigation., Marler-Clark law firm blog. 
http://www.salmonellalitigation.com/salmonella_caseupdates/view/alamosa_colorado_municipal_water_syste $\mathrm{m} \_$salmonella_outbreak_litigation, accessed 11/11/16.

28. McFarland, P.H. with Anderson, M. 2016. Crisis in Flint Underscores a National Problem. ENR Online. 10/12/16, http://www.enr.com/articles/40518-crisis-in-flint-underscores-a-national-drinking-water-qualityproblem?v=preview, accessed 11/12/16.

29. O'Connor, D.R. 2002. Part I Report Walkerton Disease Outbreak, Pipeline, v17:2. P 1. http://www.ohd.hr.state.or.us/dwpVol.17.

30. O'Connor, D.R. 2002a. Part Two: A Summary Report of the Walkerton Inquiry: The Events of May 2000 and Related Issues, Ontario Ministry of the Attorney General, Queen's Printer for Ontario. Toronto, ON.

31. PL-89-298, 1965. Flood Control Act: Public Law 89-298, 89th Congress, S. 2300, https://www.fws.gov/ habitatconservation/Omnibus/R\&HA1965.pdf

32. Shepardson, D. 2016. Two former Flint officials blame state and feds for water crisis, Reuters, http://www.reuters.com/article/us-michigan-water-idUSKCN0WG2N0, accessed 11/22/16.

33. Thompson, J.D.; White, M.C.; Harrington, G.W. and Singer, P.C. 1997, Enhanced Softening: Factors influencing DBP Precursor Removal, JAWWA, v89:6, 94-105.

34. Tucker. Young, Jackson and Tull, Inc. 2013. City of Flint Water Supply Assessment State Of Michigan Contract No. 271N3200089, Tucker. Young, Jackson and Tull, Inc, Detroit, MI.

35. U.S. Environmental Protection Agency. 2016, Quick Guide To Drinking Water Sample Collection, USEPA, Region 8, Golden, CO.

36. U.S. Environmental Protection Agency. 2016a. Analytical Methods Approved for Drinking Water Compliance Monitoring under the Disinfection Byproduct Rules, USEPA. Washington, DC, https://www.epa.gov/ dwanalyticalmethods/approved-drinking-water-analytical-methods, accessed 5/11/17.

37. U.S. Environmental Protection Agency., 2011. Analytical Methods Approved for Drinking Water Compliance Monitoring under the Disinfection Byproduct Rules. USEPA, Cincinnati, OH. https://nepis.epa.gov/ Exe/ZyNET.exe/P100PHKC.TXT?ZyActionD=ZyDocument\&Client=EPA\&Index $=2011+$ Thru $+2015 \&$ Docs $=\&$ Query $=\&$ Time $=\&$ EndTime $=\&$ SearchMethod $=1 \&$ TocRestrict $=$ n $\&$ Toc $=\&$ TocEntry $=\& Q F i e l d=\&$ QField Year $=\&$ QFieldMonth $=\& Q$ FieldDay $=\&$ IntQFieldOp $=0 \&$ ExtQFieldOp $=0 \&$ XmlQuery $=\&$ File $=\mathrm{D} \% 3 \mathrm{~A} \% 5$ Czyfiles $\% 5$ CInde x\%20Data\%5C11thru15\%5CTxt\%5C00000022\%5CP100PHKC.txt\&User=ANONYMOUS\&Password=anonymou s\&SortMethod=h\%7C-\&MaximumDocuments=1\&FuzzyDegree=0\&ImageQuality=r75g8/r75g8/x150y150g16/ i425\&Display $=$ hpfr\&DefSeekPage $=\mathrm{x} \&$ SearchBack $=$ ZyActionL\&Back $=$ ZyActionS\&BackDesc $=$ Results\%20page\& MaximumPages $=1 \&$ ZyEntry $=1 \&$ SeekPage $=x \& Z y$ PURL

38. U.S. Environmental Protection Agency. 2010. Comprehensive Disinfectants and Disinfection Byproducts Rules (Stage 1 and Stage 2): Quick Reference Guide, Office of Water (4606M) EPA 816-F-10-080 http://water. epa.gov/drink, Washington, DC.

39. U.S. Environmental Protection Agency. 2005, Quick Guide To Drinking Water Sample Collection, USEPA, Region 8, Golden, CO.

40. U.S. Environmental Protection Agency. Winter 2004. 2004 Edition of the Drinking Water Standards and Health Advisories, EPA 822-R-04-005 Office of Water U.S. Environmental Protection Agency Washington, DC.

41. U.S. Environmental Protection Agency. 2002. Nitrification, Office of Water, USEPA, Cincinnati, OH.

42. U.S. Environmental Protection Agency. 2002a. Chemical Health Effects Tables. http://www.epa.gov/ safewater/tcrdsr.html. May 7, 2002.

43. U.S. Environmental Protection Agency. 2002b. Microbial Health Effects Tables. http://www.epa.gov/ safewater/tcrdsr.html. May 7, 2002.

44. U.S. Environmental Protection Agency. 2001. National Primary Drinking Water Regulations. Federal Register, 19(141).

45. U.S. Environmental Protection Agency. July 2002. List of Contaminants and Their MCLs. U.S. EPA 816-F-02013

46. U.S. Environmental Protection Agency. 1994. National primary drinking water regulations; disinfectants and disinfection byproducts; proposed rule. Fed. Regist. 59, 38668-38829.

47. U.S. Environmental Protection Agency. 1989. Drinking Water; National Primary Drinking Water Regulations; Filtration, Disinfection; Turbidity, Giardia lamblia, Viruses, Legionella, and Heterotrophic Bacteria; Final Rule. Federal Register, 54(124):27486- 27541.)

48. U.S. Environmental Protection Agency. 1979. National interim primary drinking water regulations; control of the trihalomethanes in drinking water; final rule. Fed. Regist. 44, 68624-68707. 
49. Wisely, J., and R. Erb. 2015. Chemical Testing Could Have Predicted Flint's Water Crisis. Detroit Free Press, October 11, 2015. http://www.freep.com/story/news/local/michigan/2015/10/10/missed-opportunities-flintwater-crisis/73688428/ (accessed December 20, 2016).

50. Wolfe, Roy L., Nancy I. Lieu, George Izaguirre and Edward G. Means. 1990. Ammonia Oxidizing Bacteria in a Chloraminated Distribution System: Seasonal Occurrence, Distribution, and Disinfection Resistance. Appl. Environ. Microbiol., 56(2): 451-462.

51. WQHC, 2005. Walkerton Five Years After Lessons learned in the aftermath of Canada's worst E. coli Contamination, Health, Water Quality and Health Council of the American Chemistry Council. WQHC,

52. World Health Organization (2016). Global Health Observatory Data. https://www.who.int/gho/phe/ water_sanitation/burden/en/ Accessed June 13, 2019.

53. Young J. 2016. presentation in person 10/19/2016 at AWWA Council Summit, Denver Westin, Denver CO.

54. Zazouli, M.A. and Kalankesh, L.R., 2017. Removal of precursors and disinfection by-products (DBPs) by membrane filtration from water: a review, Journal of Environmental Health Science and Engineering, online. doi: $10.1186 / \mathrm{s} 40201-017-0285-\mathrm{z}$ 